Review Article

\title{
Online Food Delivery Services: Make or Break the Halal Supply Chain?
}

\author{
Nina Naquiah Ahmad Nizar ${ }^{1 *}$ and Siti Aimi Sarah Zainal Abidin ${ }^{1,2}$ \\ ${ }^{1}$ Malaysia Institute of Transportation, Universiti Teknologi MARA, 40450 Shah Alam, Selangor, Malaysia \\ ${ }^{2}$ Faculty of Applied Sciences, Universiti Teknologi MARA, 40450 Shah Alam, Selangor, Malaysia \\ *Corresponding author: Nina Naquiah Ahmad Nizar I Email: naquiah@uitm.edu.my
}

Received: 05 January 2021; Revised: 25 February 2021; Accepted: 26 February 2021; Published: 20 March 2021

\begin{abstract}
Online food delivery service (FDS) is the new gig economy in this era of new normal. Online FDS refers to the process whereby food that was ordered online is prepared and delivered to the consumer. FDS falls at the end of a food supply chain, the final stage just before the food reaches customers. However, this stage can make or break a wholesome food production, particularly in halal food supply chain. This paper revisits the guidelines of FDS in Malaysia; then extended to the measures taken during COVID-19 pandemic. The focus is food safety and quality, and halal supply chain. It is hoped that this overview will become a source of information for the public for their peace of mind, and the food delivery service providers to deliver wholesome food to their customers.
\end{abstract}

Keywords: COVID-19, food delivery service, halal logistics, food safety and quality, p-hailing

\section{INTRODUCTION}

The emergence of online food delivery services quickly became a hit among consumers especially in Southeast Asia. Highly potential, EC Insider forecasted that this sector would grow to annual revenue of USD 956 million, by year 2022 [1]. In Malaysia alone, profits in the online food delivery segment are projected at USD211 million this year (2020). Revenue is expected to show an annual growth rate (CAGR 2020-2024) of $18.0 \%$, resulting in a projected market volume of USD410 million by 2024 [2].

These statistics were accelerated by the high use of smartphones technology among people. In 2019 there were 5.2 billion smartphone connections, and by the end of 2020, it has been predicted that half of the people in the world will have access to mobile internet services [3]. More and more people have used smartphones in accommodating their daily activities. More specifically, it has also changed the purchase of products or services, including foods [4].

Previously, buying of food is only possible by visiting food outlets in-person or contacting food outlets directly to place orders before collection or delivery. Now, with the advancement of technology, an alternative mode of online ordering and delivery service that utilizes third-party platforms is the new norm [5,6]. Online FDS usually operate as intermediaries between customers and food outlets, although business models may vary from one online platform to the other [7].

However, to our knowledge, there is currently a limited understanding about the safety and quality of food items during transportation from the food outlets to customers, sold through online food delivery services. Such business also raises food hygiene considerations. The concerns of food 
safety and hygiene has risen especially in the era of COVID-19 pandemic. The World Health Organization (WHO) reported that there are approximately two million fatal cases of food poisoning occur every year globally [8]. Ineffective food handling training, the use of untreated water for nondrinking purposes, and poor sanitation and hygiene are the primary risk factors of food poisoning in the Malaysia [9]. Moreover, the information of online FDS in the halal supply chain is scarce hence raises the question of halal sanctity on foods delivered by means of this service. Therefore, this article offers a unique perspective on i) concept of online FDS; ii) the safety and quality of food via online FDS; iii) whether FDS upholds the halal supply chain; and iv) the hygiene guidelines among the FDS riders, especially during COVID-19.

\section{DISSCUSSION}

\subsection{Concept of Online Food Delivery Service (FDS)}

In Malaysia, online FDS such as Food Panda, Grab Food or Pizza Hut Delivery service is classified under the category of parcel-hailing (p-hailing) which refers to the delivery of parcels and food via online applications by means of motorcycles $[10,11]$. The riders are typically freelancers who have their own motorcycles.

The predecessor of p-hailing; the e-hailing service, has been exclusively used to define the shared mobility service facilitated by software applications (apps) [10]. The theory of 'sharing economy' becomes the basis of e-hailing services [12], in which; more innovative, dynamic and intuitive platforms have gradually replaced the traditional marketplaces of business. This transformation was driven by the rapid enhancement of the information technology and the internet [13].

Commonly, a third party developed and managed these platforms [14]. These platforms generally brought the resources of the owners together to meet the users' demands. Figure 1 presented the consumption model of a digital market in the sharing economy, where goods and services were offered, transacted, and fulfilled. A successful transaction comes with legal documentation and finalisation in ownership transfers, facilitated by effective communications between suppliers and seekers, respectively [13]. The concept of p-hailing adopts the consumption model by [13], with food delivery service as one of the popular niches. People turn to online food delivery services mainly due to the easiness, speed and convenience provided by the business.

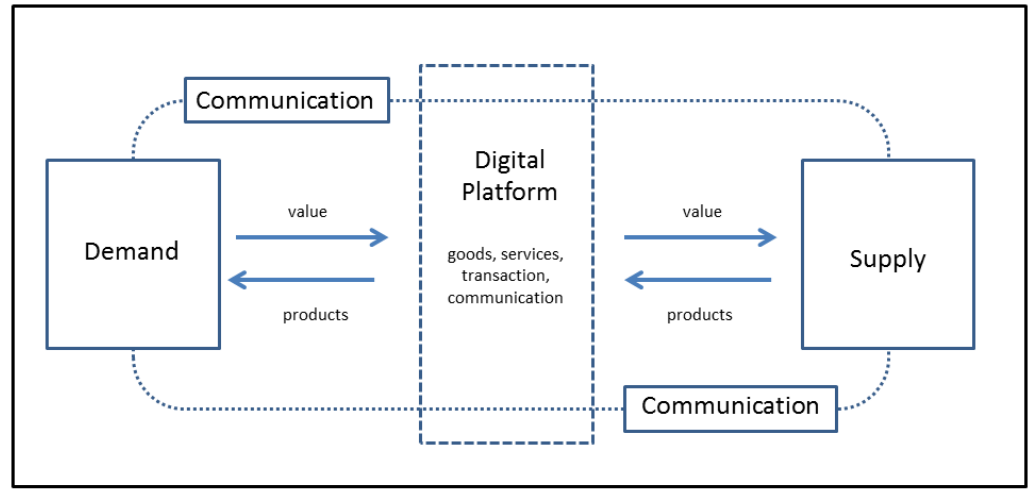

Figure 1. Shared mobility consumption model. Adapted and adopted from [13].

Consequently, $\mathrm{Li}$ and co-workers summarised a very detailed concept of online FDS as shown in Figure 2 [15]. Typical steps of online FDS is first, food producers would offer a selection of menu that shows on the online platform. Second, the customers choose and place an order on 
their desired meals. Then, there is the taking of orders, the forwarding of these orders to the food outlets and, the monitoring of payment. Next, their orders are forward to food outlets where meals are cooked, and once prepared, meals are delivered to customers by FDS with the aid of delivery tracking facilities. All these steps are made possible by food delivery applications, or food 'apps' $[6,15]$.

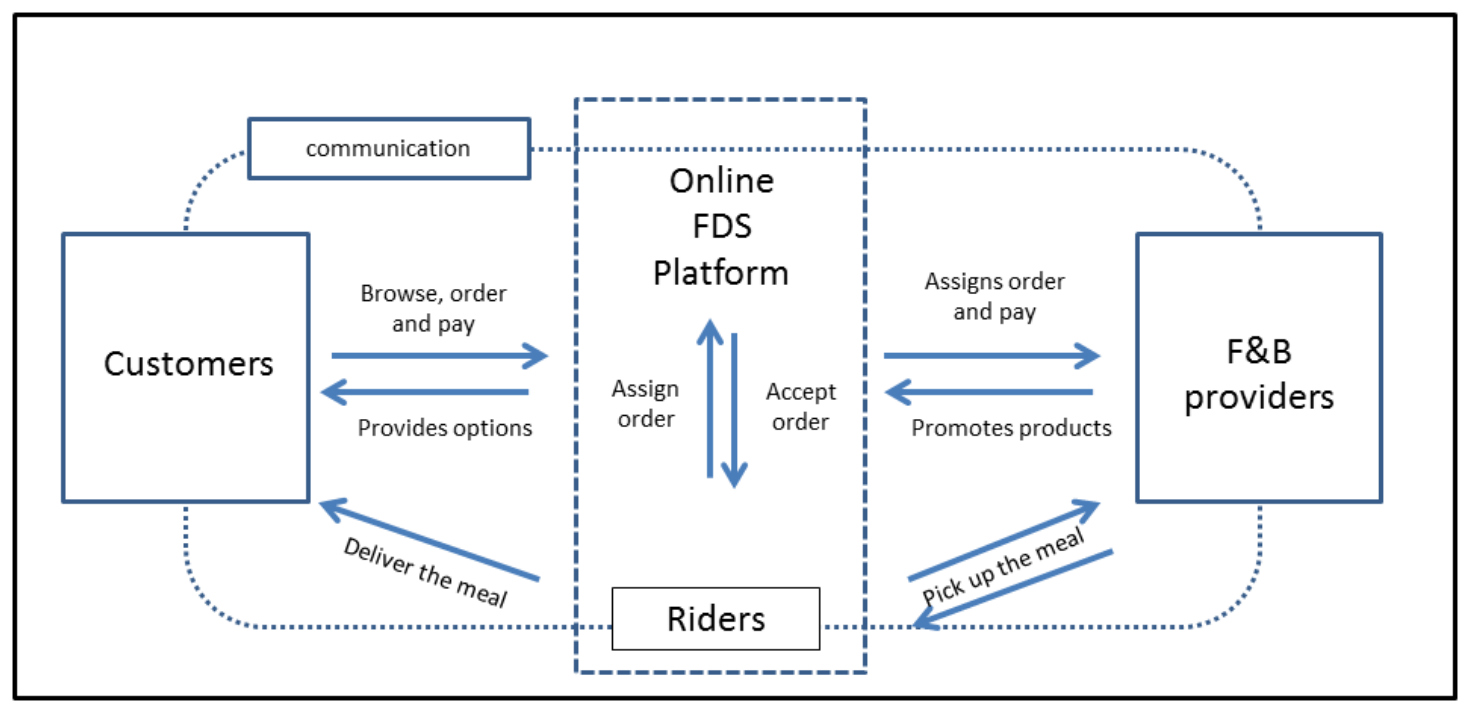

Figure 2. Online FDS concept. Adopted and adapted from [15]

Lau and David (2019) highlighted that people nowadays, especially the urbanites are living the fast-paced life and they are more adventurous in trying different range of foods, hence there will be excitement at the chance of discovering more restaurants that food delivery offers [16]. Besides, food delivery allows them to have fresh and/or healthy food readily available, at work or at home after a long day at work. This service is a revolution in the food and beverage industry because of its potential for business growth; ensuring higher employee productivity, delivering order accuracy and building important customers database.

\subsection{Food Safety and Quality in Online FDS}

Previous literature had mentioned a lot on the convenience and positive behavioural of consumers towards online FDS before, and especially during the COVID-19 pandemic $[6,15,16,17]$. Nevertheless, while such services are convenient, the intricate spatiotemporal subtleties of online food delivery networks could consequence in a new means of spreading foodborne diseases and pose previously unknown threats on public health [18]. Food poisoning proliferates due to consuming food contaminated with microorganisms or their toxins, the contamination occurred from inadequate preservation methods, unhygienic handling practices, cross-contamination from food contact surfaces, or from persons harbouring the microorganisms in their nostrils and on the skin $[19,20]$. Notably, food can be contaminated at any step of the whole food chain [21].

As for example, in July 2018, an outbreak of 10 cases of Salmonella enterica serovar Enteritidis infection occurred in Shenzhen, China. Outbreak traced the source to food ordered online. The investigation highlights the role of online food delivery platforms as a new mode of food-borne disease transmission. In contrast to traditional restaurant dining, online food delivery could send potentially contaminated food across wide geographic areas throughout a city within a short time to 
cause large-scale outbreaks. Online food delivery also poses additional food safety risks, including improper handling and storage temperature during transport [18].

In another research, Angelillo and co-researchers suggested that food handlers who had good knowledge of proper food handling practices could help to control food poisoning cases as they were in direct contact with food, particularly ready-to-eat foods [22]. However, Lee and co-workers found that the microbiological assessment of food handlers' hands around a campus in Malaysia, saw 65\% of the food handlers examined had a total aerobic count $\geq 20 \mathrm{CFU} / \mathrm{cm} 2$ and Salmonella was detected at $48 \%$ of the food handlers' hands [23]. These results shown that self-reported knowledge on hygiene is not always parallel with microbiological safety assessment which is measurable and more accurate. The contaminated hands of food handlers could easily transmit foodborne diseases through crosscontamination of food products [23].

On the other hand, an overview on potential hazards and control measures for food during FDS activities were summarized [24]. Briefly, all food must reach consumers in a safe and fit condition to eat. Foods prepared away from home often have short shelf life and requires proper storage conditions. Bacteria for example; Staphylococcus aureus, Salmonella enteritidis, Escherichia coli, and Campylobacter jejunii can proliferate at dangerous levels in food stored for a long time at ambient temperature $\left(4.4^{\circ} \mathrm{C}-60^{\circ} \mathrm{C}\right)$, causing illness to consumers [25]. As a safety measure, since pathogenic bacteria grow rapidly in the middle of the zone, between $21^{\circ} \mathrm{C}$ and $47^{\circ} \mathrm{C}$ (danger zone), consumption of any food stored at this range for more than two hours should be avoided [26]. At a minimum, food safety practices necessitate that food products are in a controlled temperature environment during FDS [27].

Apart from temperature, duration of transportation is also very crucial to ensure food safety. The time the food is stored in the danger zone must be minimized. Food that needs refrigeration must be kept cool while being transported. The food needs to be packed in an insulated box with a coolant gel or in a cool bag with a temperature of $8^{\circ} \mathrm{C}$ or below. For food that needs to be kept hot, it should be packed in an insulated bag with a temperature of above $60^{\circ} \mathrm{C}$ [25].

In order to maintain the heat/cool within the food, it is advised to keep the delivery distance short; in which a maximum of a 30 minutes radius for deliveries is recommended [24]. Lengthy delivery times or unexpected delivery delays can compromise the quality and appeal of cooked or prepared food. Additionally, proper packaging of foods is pivotal to prevent infiltration from potentially harmful bacteria [27]. In a nutshell, the FDS should be vigilant on keeping the food at the right temperature, deliver within stipulated time, keep the transportation bag or tools clean and in good condition, and keep up a goof self-hygiene, which will be discussed further later in this article. These control measures could minimize the risks of food safety and quality towards online FDS.

\subsection{How can FDS contribute to a wholesome halal supply chain?}

Consumption of halal food is becoming significant as it associates with quality, cleanliness, and safety as highlighted by the Shariah principles [28]. Halal involves the whole supply chain network right from the origin to final consumption, from farm-to-fork [29]. A complete food production supply chain mainly consists of i) production; ii) processing; iii) distribution; iv) retail; and v) consumer [30]. To cope with the growing demand of halal food from all over the world, a comprehensive and well managed supply chain management approach need to be adopted to ensure the availability of the halal food products [31]. FDS is no exception. Positioned at the end of 
the food chain, just before the food products reach the customers, it is imperative to ensure that the halal food supply chain be sustained.

Halal food supply chain encompasses the process of halal food products management at different points of suppliers to different points of buyers/consumers. This involved several different entities, located at different places, who may at the same time, involved with managing non-Halal food products, with the objective of fulfilling the needs and requirements of both (halal and nonhalal) customers. In a halal food supply chain, the focus is to achieve customer's satisfaction as well as to guarantee that the halal status of the food product remains all through the process of the supply chain [32].

The integrity of the halal food product must be protected at all times and all required steps must be taken by all parties involved in the supply chain to avoid any cross contamination that will lead to product becoming non-halal, or haram. The food products must not only be halal at the supply chain starting point but throughout the supply chain until it reaches its final destination [31]. The product can be halal at the time at the pick-points or food outlets, but if not handled properly, the halal status could be at stake. This is where online FDS can make or break the halal supply chain. Therefore, awareness on halal supply chain among food deliverers is vital. They need to acknowledge on the importance of their job and do it righteously.

Four issues were summarized in relation to transportation in halal supply chain [33]. Although the issues aroused in logistics, three of them can be proposed and applied in food delivery services too. First, cross contamination issue during delivery and transport due to contaminated containers (delivery bags). This may happen when the halal product come into physical contact with haram or/and hazardous substance during delivery done beforehand by the same transport [34]. Second, the lack of dedicated assets and facilities in handling halal products when passing consignments, if the latter did not practise halal logistics [35]. Third, practice of sharing containers, which is the segregation by allocation of space between halal and non-halal goods in same containers; increased the risk towards halal integrity being compromised [36]. Lastly, difficult tracking and tracing the driver's attitudes and procedures practiced at interval stops during the delivery of halal products [29]. This holds true to Wildes (2005) who highlighted the most critical component in an effective delivery service system is the human element [37]. Subsequently, three possible cross contamination in FDS may happen in the containers which does not separate halal and non halal foods, the sharing of containers for halal and non-halal products and third; human element whereby halal integrity may be the issue.

With the highlighted challenges, there should be a guideline to food deliverers in terms of upholding the halal supply chain. First, the online FDS should consider usage of separate bags for halal and non-halal foods during delivery. Deliveroo and Grabfood Singapore, has applied this measure since 2018 to cater for the wide pool of halal restaurants. The bags are sturdy and can prevent any leakage or potential contamination from other foods. All the riders are to use the halalonly bags when assigned to an order from a halal-certified restaurant. Second, no sharing of containers or bags for halal and non-halal food should occur. This could avoid the needs for Shariah ritual cleansing or called sertu cleansing procedure for transport containers carrying halal products (MS2400:2010) [38]. Deliveroo Singapore added that when halal orders are packaged individually by the restaurants, there is an additional layer of protection to maintain the halal chain [39]. Third, the riders need to fathom the importance of guidelines on food quality, safety, cleanliness and halal 
when involved in online FDS. This minimizes the chance to temper on the halal integrity while in service [29]. The halal food industry is reliant on consumer trust of its food integrity, so the players in the halal supply chain hold the same responsibilities in ensuring that all the products always fulfil the requirements [40]. Hence, in terms of halal supply chain, it is timely these proposed guidelines to the food deliverers be looked into so both food providers and consumers can have their peace of mind, and online FDS can contribute to a wholesome halal supply chain.

\subsection{Food Delivery Services during Covid-19 Pandemic}

The coronavirus has restructured the economic setting where profound adjustments are required among consumers, creating to new habits during lockdowns and quarantines. The demand for better hygiene, cleaner and safer products have risen among the consumers concerning the pandemic. Everyone is striving to adapt to a new normal, altering the consumer behaviour and lifestyle. As this change continues, digital-commerce has seen a boost as consumers migrate online to get their products and services [41].

In the food sector, online FDS provided a critical lifeline during the 2020 COVID-19 pandemic for many people quarantined at home. Besides providing meals, many who've lost their jobs turn to FDS as a new way to earn a living. Online FDS limits the face-to-face contact among consumers, food providers and delivery people. The most recent advice from the WHO is that current evidence indicates that COVID-19 virus is transmitted during close contact through respiratory droplets (formed on coughing or sneezing) and by fomites. This poses a unique challenge for food delivery riders. The food deliverers are possibly amongst those at highest risk of exposure due to the number of people they see daily. Hence, preventive measures are essential and several guidelines need to be adhered to [41].

In order to strictly control online FDS during the pandemic, the World Health Organization (WHO), Food and Agricultural Organization of the United Nations (FAO), US Food Drug Administration (FDA), Food Standards Agency in the United Kingdom, have provided guidance, which includes practical advice to customers, to businesses selling food online as well as to local authorities $[42,43,44]$. This includes highlights on best practices for food pick-up or delivery services. In addition, in China, food safety practices through online FDS came into the attention due to the report of foodborne illness incidents that stemmed from the microbiological risk of online food [45]. Therefore, the government of China has published the amendments to the Implementing Regulations of the Food Safety Law enforcing online food businesses to monitor food and carry out food examinations to ensure that the online food products are legally sourced, safely stored and transferred [46]. Additionally, in Malaysia, the Ministry of Transport, has categorised FDS under phailing; and released guidance to curb the spread of COVID-19 in the times of Controlled Movement Order in April 2020.

Primarily, the aim of any extra measures on hygiene and sanitation implemented by food businesses is to keep the COVID-19 virus out of their businesses. The virus will enter business premises only when an infected person enters or contaminated products or items came into the premises. Hence, the food businesses should follow best practices emphasized by the experts to prevent any possibility of infection. FDS riders may have high risk of getting infected due to the number of people they see daily [41]. 
Therefore, WHO highlighted several guidelines for the delivery riders; i) Drivers and other staff delivering to food premises should not leave their vehicles during delivery ii) Drivers should be supplied with masks, an alcohol-based hand sanitizer, a disinfectant, and paper towels; iii) Drivers should use a hand sanitizer before passing delivery documents to food premises staff; iv) Disposable containers and packaging should be used to avoid the need for cleaning of any returns. In the case of reusable containers, appropriate hygiene and sanitation protocols should be implemented; v) Drivers delivering to food premises should be aware of the potential risks involved in contact transmission of COVID-19; vi) Drivers need to be aware of physical distancing when picking up deliveries and passing deliveries to customers; vii) and of the need to maintain a high degree of personal cleanliness and to wear clean protective clothing; viii) Drivers also need to be aware of the need to ensure that all transport containers are kept clean and frequently disinfected, foods must be protected from contamination, and must be separated from other goods that may cause contamination [42].

Subsequently, FDA and Centres for Disease Control and Prevention (CDC) suggested that employees including food deliverers wash hands often with soap and water for at least 20 seconds, especially after going to the bathroom, before eating, after blowing their nose, coughing or sneezing, or after touching high touch surfaces, for example, on steering wheels, door handles, mobile devices doorknobs, and doorbells. An alcohol-based hand sanitizer with at least $60 \%$ alcohol can be used if there is no soap and water $[43,47]$.

Poor personal hygiene, primarily ineffective hand washing, unhygienic practices during food preparation, handling and storage creates the conditions that allows the proliferation and transmission of disease-causing organisms such as bacteria, viruses and other food-borne pathogens [48]. Hand hygiene is the most basic yet critical criterion for ensuring safe food handling by food handlers. In fact, hand washing has long been known to be a fundamental precautionary measure in health care settings [49], as well as in the kitchen, for preventing the spread of infectious disease through human to human or human to food contact [50,51,52,53].

Next, ensure any wrapping and packaging used for food transport is done so that contamination of the food is prevented. Practice social distancing when delivering food, e.g., offering "no touch" deliveries and sending text alerts or calling when deliveries have arrived [54]. The virus can infect if drivers touch a contaminated surface or shake hands with an infected person with contaminated hands. This is why hand hygiene and physical distancing, is of paramount importance and why contact surface sanitation is critical to avoid cross-contamination [42]. On top of that, to minimize the impact to the environment, it is essential that all riders be responsible of their masks and gloves by disposing them properly [54].

Thus, by providing the food delivery riders with the right resources, they can combat probabilities of infection. This will not only benefit the riders, but the community as a whole, to contain the spread of this virus. A personal hygiene and adherence to guidelines and preventive measures go a long way and will eventually lead to a more promising path ahead.

\section{CONCLUSION}

Online FDS is a complex system that eases the customers on getting food at their desired taste, time and place. Although, an integrated approach on the issues of the food safety and quality; cleanliness and personal hygiene among food handlers at the end of the supply chain (online FDS) is essential and requires more resources as an addition to the food literature, especially on halal supply 
chain. This information can guide as well as maintain the halal and food integrity in an online FDS system to ensure improvement of halal supply chain.

\section{References}

1. The food delivery battle has just begun in Malaysia. Available online:https://www.ecinsider.my/2018/02/food-delivery-companies-malaysia.html $\quad$ (accessed on 12 November 2020)

2. Online Food Delivery Malaysia. Available online: https://www.statista.com/outlook/374/122/online-fooddelivery/malaysia\#market-age (accessed on 5 November 2020)

3. The Mobile Economy 2020. Available online: https://archive.is/2Xhj1 (accessed on 12 November 2020).

4. Yusra; Agus, A. The influence of online food delivery service quality on customer satisfaction and customer loyalty: The role of personal innovativeness. Journal of Environmental Treatment Techniques 2020; 8,1, 6-12.

5. Maimaiti, M.; Zhao, X.; Jia, M.; Ru, Y.; Zhu, S. How we eat determines what we become: Opportunities and challenges brought by food delivery industry in a changing world in China. Eur. J. Clin. Nutr. 2018, 72, 1282-1286.

6. Keeble, M.; Adams, J.; Sacks, G.; Vanderlee, L.; White, C.M.; Hammond, D.; Burgoine, T. Use of Online Food Delivery Services to Order Food Prepared Away-From-Home and Associated Sociodemographic Characteristics: A Cross-Sectional, Multi-Country Analysis. International Journal of Environmental Research and Public Health 2020, 17, 5190.

7. Allen, J.; Piecyk, M.; Piotrowska, M.; McLeod, F.; Cherrett, T.; Ghali, K.; Nguyen, T.; Bektas, T.; Bates, O.; Friday, A.; Wise, S.; Austwick, M. Understanding the Impact of E-commerce on Last-Mile Light Goods Vehicle Activity in Urban Areas: The Case of London. Transportation Research Part D: Transport and Environment. 2018, 61, Part B, 325-338.

8. Food Safety; WHO: Geneva, Switzerland, 2015. Available online: http://www.who.int/mediacentre/factsheets/fs399/en/ (accessed on 12 November 2020)

9. Ministry of Health (MOH) Annual Report 2010; MOH: Putrajaya, Malaysia, 2012.

10. Laws of Malaysia. Land Public Transport (Amendment) Act 2017., Pub. L. No. A1552, 2017.

11. Kenyataan Media Kementerian Pengangkutan Malaysia.Tajuk: garis panduan untuk perkhidmatan penghantaran makanan dan bungkusan menggunakan motosikal (parcel hailing $-p$ hailing). Available online: $\quad$ http://cccovid19.mot.gov.my/assets/images/preview/20042020_GARIS_PANDUAN_PHAILING_KENYATAAN_MEDIA_YBM(1).pdf (accessed on 5 November 2020).

12. Hawlitschek, F.; Teubner, T.; Gimpel, H. Understanding the Sharing Economy - Drivers and Impediments for Participation in Peer-to-Peer Rental by Understanding the Sharing Economy. 49th Annual Hawaii International Conference on System Sciences (HICSS), 4801. Kauai Hawaii. 2016.

13. Jais, A.S.; Marzuki, A. E-hailing services in malaysia: current practices and future outlook. Planning Malaysia: Journal of the Malaysian Institute of Planners, 2020, 18, 3, 128 - 141.

14. Li, Z.; Hong, Y.; Zhang, Z. An empirical analysis of on-demand ride sharing and traffic congestion. Hawaii International Conference on System Sciences 2017, 1- 13.

15. Li, C.; Mirosa, M.; Bremer, P. Review of Online Food Delivery Platforms and their Impacts on Sustainability. Sustainability 2020, 12, 5528.

16. Lau, T.C.; David, N.C.T. Online Food Delivery Services: Making Food Delivery the New Normal. Journal of Marketing Advances and Practices 2019, 1, 62-67. 
17. Dang, A. K.; Tran, B. X.; Nguyen, C. T.; Le, H. T.; Do, H. T.; Nguyen, H. D.; Nguyen, L. H.; Nguyen, T. H.; Mai, H. T.; Tran, T. D.; Ngo, C.; Vu, T. T. M.; Latkin, C. A.; Zhang, M.W.B.; Ho, R.C.M. Consumer Preference and Attitude Regarding Online Food Products in Hanoi, Vietnam. Int. J. Environ. Res. Public Health 2018, $15,981$.

18. Jiang, M.; Zhu; Yang, C.; Deng, Y.; Kwan, P.S.L.; Li, Y.; Lin,Y.; Qiu, Y.; Shi, X.; Chen, H.; Cui, Y; Hu, Q. Whole-Genome Analysis of Salmonella enterica Serovar Enteritidis Isolates in Outbreak Linked to Online Food Delivery, Shenzhen, China. Emerging Infectious Diseases 2018, 26, 4, 789-792.

19. Barrie, D. The provision of food and catering services in hospital. J Hosp Infect. 1996, 33, 1, $13-33$.

20. Jay, L.S.; Comar, D.; Govenlock, L,D. A video study of Australian domestic food-handling practices. J Food Prot. 1999, 62, 11, 1285-96.

21. Nyachuba, D.G. Foodborne illness: is it on the rise? Nutr Rev. 2010, 68, 257-69.

22. Angelillo, I.F.; Viggiani, N.M.; Rizzo, L.; Bianco, A. Food handlers and foodborne diseases: Knowledge, attitudes, and reported behavior in Italy. J. Food Prot. 2000, 63, 381-385.

23. Lee, H.K.; Halim, H.A.; Thong, K.L.; Chai, L.C. Assessment of Food Safety Knowledge, Attitude, SelfReported Practices, and Microbiological Hand Hygiene of Food Handlers Int. J. Environ. Res. Public Health 2017, 14, 55 .

24. Bujang, A.; Ain, N.; Nurfadzliyana; Sarah, S.A. An overview of potential hazards and control measures of food delivery service activities. Advances in Transportation and Logistics Research in Global Research on Sustainable Transport \& Logistics 2020, 3, 892-898.

25. Risk-based food inspection manual, Food and Nutrition Paper 89, Food and Agriculture Organization of The United Nations (FAO), Rome. 2008.

26. Singh, P. K.; Singh, R. P.; Singh, P.; Singh, R. L. Food Hazards: Physical, Chemical, and Biological. Food Safety and Human Health, 2019, 15, 65.

27. Validating the quality of food delivery services. Available online: https://www.tuvsud.com/en/essentials-newsletter/food-and-health-essentials/e-ssentials-2-2018/validating-the-quality-of-food-deliveryservices (accessed on 7 November 2020).

28. Jaafar, H. S.; Endut, I. R.; Faisol, N.; Omar, E. N. Innovation in logistics services-halal logistics. In 16th International Symposium on Logistics (ISL), 2011, 844-851.

29. Talib, M.S.A.; Rubin, L.; Vincent, K.Z. Qualitative Research on Critical Issues In Halal Logistics. Journal of Emerging Economies and Islamic Research 2013, 1, 2, 1-20.

30. Bangun, P. N. Food Production: From farm to fork. In Preparation and Processing of Religious and Cultural Foods. Eds Ali, M.E., and Nizar., N.N.A. Woodhead Publishing, United Kingdom. 2018, pp 3-12.

31. Zulfakar, M. H.; Jie, F.; Chan, C. Halal food supply chain integrity: from a literature review to a conceptual framework. In 10th ANZAM Operations, Supply Chain and Services Management Symposium, 2012.

32. Bahrudin, S.S.M.; Illyas, M. I.; Desa, M.I. Tracking and tracing technology for halal product integrity over the supply chain in Proceedings of the Computer Science International Conference on Electrical Engineering and Informatics, 2011.

33. Supian, K. Cross Contamination in processing, packaging, storage, and transport in halal supply chain. In Preparation and Processing of Religious and Cultural Foods. Eds Ali, M.E., and Nizar., N.N.A. Woodhead Publishing, United Kingdom. 2018, pp, 309-318.

34. Zulfakar, M. H.; Anuar, M.M.; Talib, M.S.A. Conceptual Framework on halal food supply chain integrity enhancement. Procedia Soc. Behav. Sci. 2014, 121, 58-67. 
35. Omar, E. N.; Jaafar, H. S. Halal supply chain in the food industry-A conceptual model, in IEEE Symposium on Business, Engineering and Industrial Applications (ISBEIA), Langkawi, Malaysia, 2011, 384-389.

36. Sham, R.; Rasi, R.Z.; Abdamia, N.; Mohamed S.; Bibi, T. Halal Logistics Implementation in Malaysia: A Practical View. In the IOP Conf. Series: Mater. Sci. Eng. 2017.

37. Wildes, V. J. Stigma in food service work: How it affects restaurant servers' in- tention to stay in the business or recommend a job to another. Tourism and Hospitality Research, 2005, 5, 3, 213-233.

38. Ahmad, N.; Shariff, S.M., Supply Chain Management: Sertu Cleansing for Halal Logisitics Integrity. Procedia Economics and Finance 2016, 37, 418-425.

39. Food Delivery App Attracts Singapore Muslims with Halal Bags. Available online: https://aboutislam.net/muslim-issues/asia/food-delivery-app-attracts-singapore-muslims-halal-bags/ (accessed on 11 November 2020).

40. Ali, M.H.; Suleiman, N. Eleven shades of food integrity: A halal supply chain perspective. Trends in Food Science \& Technology 2018, 71, 216-224.

41. World Halal Conference 2020 to focus on halal industry embracing the new world economy. Available online: http://mrem.bernama.com/viewsm.php?idm=38319 (accessed on 10 November 2020).

42. Is it safe and ethical to order meals online during the coronavirus outbreak? https://archive.is/gw6G6\#selection-1713.0-1713.574 WHO/ FAO 2020 (accessed on 10 November 2020).

43. USFDA Best Practices for Retail Food Stores, Restaurants, and Food Pick-Up/Delivery Services During the COVID-19 Pandemic. Available online: https://www.fda.gov/food/food-safety-during-emergencies/bestpractices-retail-food-stores-restaurants-and-food-pick-updelivery-services-during-covid-19 (accessed 9 November 2020).

44. Food safety for food delivery. Available online: https://www.food.gov.uk/business-guidance/food-safetyfor-food-delivery (accessed on 8 November 2020).

45. Ma, J. Online Shopping and Food Safety; Center for Food Safety: Hong Kong, China. 2015.

46. CFDA Issued the World's First Investigation Measures on Illegal Behavior of Online Food Safety. Available online: http://www.cirs-reach.com/news-and-articles/cfda-issued-the-world-first-investigation-measureson-illegal-behavior-of-online-food-safety.html (accessed on 12 November 2020).

47. How to Protect Yourself \& Others Available online: https://www.cdc.gov/coronavirus/2019-ncov/preventgetting-sick/prevention.html (accessed on 10 November 2020).

48. Curtis, V.; Cairncross, S. Effect of washing hands with soap on diarrhea risk in the community: A systemic review. Lancet Infect. Dis. 2003, 3, 275-281.

49. Evidence of hand hygiene to reduce transmission and infections by multidrug resistant organisms in health-care settings. In WHO Guidelines on Hand Hygiene in Health Care; Clean Care is Safer Care Team, Ed.; WHO: Geneva, Switzerland, 2009.

50. Gibson, L.L.; Rose, J.B.; Haas, C.N.; Gerba, C.P.; Rusin, P.A. Quantitative assessment of risk reduction from hand washing with antibacterial soaps. J. Appl. Microbiol. 2002, 92 (Suppl. S1), 136S-143S.

51. Chinakwe, E.C.; Nwogwugwu, N.U.; Nwachukwu, I.N.; Okorondu, S.I.; Onyemekara, N.N.; NdubuisiNnaji, U.U. Microbial quality and public health implications of hand-wash water samples of public adults in Owerri, South-east Nigeria. Int. Res. J. Microbiol. 2013, 3, 144-146.

52. Soares, L.S.; Almeida, R.C.C.; Cerqueira, E.S.; Carvalho, J.S.; Nunes, I.L. Knowledge, attitudes and practices in food safety and the presence of coagulase-positive staphylococci on hands of food handlers in the schools of Camaçari, Brazil. Food Control 2012, 27, 206-213. 
53. Perez-Rodriguez, F.; Valero, A.; Carrasco, E.; Garcia, R.M.; Zurera, G. Understanding and modelling bacterial transfer to foods: A review. Trends Food Sci. Technol. 2008, 19, 131-144.

54. Food Delivery and Takeout in the Pandemic Age Available online: https://www.foodqualityandsafety.com/article/food-delivery-and-takeout-in-the-pandemic-age/ (accessed on 8 November 2020).

(c) 2021 by the authors. Submitted for possible open access publication under the terms and conditions of the Creative Commons Attribution (CC BY) license (http://creativecommons.org/licenses/by/4.0/). 